\section{A New Triol from the Urine of Pregnant Mares}

Recentruy, Dr. André Girard very kindly placed at our disposal a large quantity of an extract of the urine of pregnant mares from which the ketohydroxyœstrin had been previously removed. Attempts to isolate from the neutral fraction of this extract, the sterol degradation product pregnandiol, $\mathrm{C}_{21} \mathrm{H}_{36} \mathrm{O}_{2}$, which occurs in the neutral ether-soluble fraction of human pregnancy urine, have not been successful. We have, however, isolated from this same fraction a new crystalline substance, m.p. $300^{\circ}$ (decomp.); $[\alpha]_{5461}$ (in pyridine) $=-44^{\circ}$, which has given combustion figures agreeing closely with the formula $\mathrm{C}_{21} \mathrm{H}_{36} \mathrm{O}_{3}$. Acetylation has yielded a triacetate, $\mathrm{C}_{27} \mathrm{H}_{42} \mathrm{O}_{6}$, m.p. $169^{\circ}$. The compound gives an iodine value of 0 by the Rosenmund-Kuhnhenn method. The colour given by it when treated with hot concentrated sulphuric acid is similar to that given by pregnandiol under the same conditions.

In view of the source from which it was obtained, its solubilities and its empirical formula, we consider that it is probable that it is closely related to pregnandiol. Full experimental details will shortly be published.

\section{E. R. Sмith.}

D. Hughes.

G. F. Marrian.

G. A. D. Haslewood.

Dept. of Physiology and Biochemistry,

University College, London. June 15.

\section{Forest Fires in Relation to Soil Fertility}

IN his interesting article in Nature of June $3, p$. 787 , Prof. F. P. Worley describes some of the effect of fire upon soils. It is not impossible that his observations may apply to soils in tropical Africa, even in the open woodlands where the humus content is low, and leaves are consumed by fire each year.

Soil burning to obtain fertility has recently come under observation in Nyasaland, where two principles emerge. 'The first is that burning of timber (on red earth soils) producing a moderate intensity of heat, is a common practice before growing crops of maize. Cultivation continues for some years before moving. The second method is for the purpose of growing finger millets (Eleusine). Wood from a considerable area is stacked together three feet deep on the area intended for cultivation, and some months later is burned, causing a very intense heating of the soil. One good crop of Eleusine is grown, after which the land must be abandoned for some years. The effect of burning is not only to produce a friable and sterilised seed-bed. The manurial value of the wood ash is regarded as negligible by the natives. Some experiments by Moffat ${ }^{1}$ confirm the suggestion that good cultivation and the use of more common manures is no substitute for firing for producing large grains and a heavy yield.

Curiously enough, in Cornwall, at least one golf course maintains the quality of its greens by a compost of decaying vegetable matter and earth which is kiln heated to $212^{\circ}-220^{\circ} \mathrm{F}$. It is then applied as a light dressing. The value of this dressing is attributed mainly to the heated earth itself rather than to the burnt vegetable matter.

The destructiveness of Eleusine cultivation must be seen to be believed, in removal of forest and rendering the soil barren and liable to erosion. In
1932 the Conservator of Forests observed Eleusine cultivation to be on a very much larger scale than had previously been supposed, being grown also in small patches in maize gardens throughout Nyasaland. The method of heating the small patches is the same as for heating a large area. Fresh patches are sown each year within the garden until the whole garden has been burnt over and left to fallow for a number of years. The growth of the surrounding maize obscures the destructive growing of the Eleusine. This observation probably explains much shifting cultivation of maize being brought about more quickly than is otherwise necessary.

\section{Oxford.}

P. Tорнам.

June 17.

${ }^{1}$ N. Rhodesia'Agricultural Bulletin, 1932.

\section{Origin of the Time Pendulum}

Tнолgн the promulgators of the c.G.s. system were devout decimalists, they strangely took for time the solar day divided by 86,400 , instead of the day divided by 100,000 for the unit. If we take the natural standard of day divided by $10^{5}$, the pendulum would be $29 \cdot 157$ in. at lat. $30^{\circ}$. Now this is exactly the basis of the Egyptian land measures, most precisely known by the diagonal of that squared, being the Egyptian double cubit. This value for the cubit is 20.617 in., while the best examples in stone are $20 \cdot 620 \pm 0.005 \mathrm{in}$.

This close coincidence raises the question whether the highly mechanical Egyptians of the IVth dynasty had experimented with the pendulum, and adopted the hundred-thousandth of the solar day. No difficulty stood in the way, for they counted cattle up to millions. The most practical course would be to swing a pendulum of 116 in., and tick off on papyrus rows of ten swings, during the 50,000 swings between sunrise and sunrise. All that would be easily within their abilities, and a dozen such experiments would suffice to find the true value. Can we allow that the exact coincidence here will give them the credit of the first time pendulum ? This unit length divided by 40 is the basis of the Greek foot of $12 \cdot 150 \mathrm{in}$. and the Roman foot of $11 \cdot 66$ in.

Flinders Petrie.

\section{Position of Page Numbers in Books}

How many months, weeks, or at the very least, days, are wasted in each year by the habit of publishers and printers of omitting the page number at the beginning of a new chapter or article? When one is making a reference to a paper it is excessively annoying to have almost invariably to turn over the leaf in order to find the number of the page on which the chapter or article begins. Certainly it must occupy several minutes of my time each year, and the total time wasted by scientific writers and others who are careful in giving their references must certainly be considerable. If the printer or publisher objects to putting the page number in its usual place at the top outer corner of the page, he could quite easily centre it or place it at the bottom of the page. This, in fact, is a procedure occasionally adopted, especially of late years, but one would like to see it universal.

F. A. BATHER.

46 Marryat Road,

Wimbledon, S.W.19. 